ISSN 2723-7583 (Online)

\title{
STRUKTUR KOMUNITAS MAKROZOOBENTOS EPIFAUNA PADA EKOSISTEM LAMUN, MANGROVE DAN TERUMBU KARANG DI DESA LABUHAN KECAMATAN SEPULU BANGKALAN \\ STRUCTURE OF MACROZOOBENTHOS EPIFAUNA COMMUNITY ON SEAGRASS, MANGROVE AND CORAL REEF ECOSYSTEMS AT DESA LABUHAN VILLAGE, SEPULU DISTRICT OF BANGKALAN
}

\author{
M. Risda Elfahmi ${ }^{1 \star}$ dan Makhfud Efendy ${ }^{2}$ \\ ${ }^{1}$ Mahasiswa Program Studi Ilmu Kelautan, Jurusan Kelautan dan Perikanan Fakultas Pertanian, \\ Universitas Trunojoyo Madura \\ ${ }^{2}$ Program Studi IImu Kelautan, Jurusan Kelautan dan Perikanan Fakultas Pertanian, Universitas \\ Trunojoyo Madura
}

*Corresponding author e-mail: risdaelfa998@gmail.com

Submitted: 31 August 2020 / Revised: 31 August 2020 / Accepted: 31 August 2020

http://doi.org/ 10.21107/juvenil.v1i2.8446

\begin{abstract}
Macrozoobenthos is basic aquatic organism that live on the surface (Epifauna) or inside (Infauna) the basic substrate that lives sessile in coastal ecosystem in the form of mangrove, seagrass and coral reef ecosystems. Macrozoobenthos can be used as a biological parameter in determining water quality. The aim of the research is 1 . Knowing the results of measurements of water quality parameters in each research location point 2. Knowing types of makrozoobenthos (epifauna) in seagrass, mangrove and coal reef ecosystems 3. Knowing the structure of the macrozoobenthos community. The data retrieval is done using purposive sampling method. Based on the results of observations, there were 15 types of 3 macrozoobenthos phylum, namely phylum of Mollusca, Echinodermata and Arthropoda. From the calculation of the community structure of macrozoobenthos in the mangrove ecosystem, the value of the diversity index $\left(H^{\prime}\right)$ is low, the uniformity index $(E)$ is moderate and the dominance index $(C)$ is high. The seagrass ecosystem and coral reef have moderate $\left(H^{\prime}\right)$ diversity values, high $(E)$ uniformity index and low (C) dominance index.
\end{abstract}

Keywords: Community Structure, Macrozoobenthos Epifauna, Seagrass, Mangroves, Coral Reefs.

\begin{abstract}
ABSTRAK
Makrozoobentos merupakan organisme dasar perairan yang hidup dipermukaan (Epifauna) atau didalam (Infauna) substrat dasar yang hidup sesil pada ekosistem pantai yang berupa ekosistem mangrove, lamun dan terumbu karang. Makrozoobentos dapat digunakan sebagai parameter biologis dalam menentukan kualitas perairan. Penelitian ini bertujuan untuk 1. Mengetahui hasil pengukuran parameter kualitas perairan ditiap titik lokasi penelitian 2. Mengetahui jenis-jenis makrozoobentos (epifauna) pada ekosistem lamun, mangrove dan terumbu karang 3. Mengetahui struktur komunitas makrozoobentos. Pengambilan data dilakukan dengan menggunakan metode purposive Sampling. Berdasarkan hasil pengamatan didapatkan 15 jenis dari 3 filum makrozoobentos yaitu filum Mollusca, Echinodermata dan Arthropoda. Hasil perhitungan struktur komunitas makrozoobentos pada ekosistem mangrove mendapatkan nilai indeks keanekaragaman ( $\left.H^{\prime}\right)$ yang rendah, indeks keseragaman (E) sedang dan indeks dominasi (C) tinggi. Ekosistem lamun dan terumbu karang memiliki nilai keanekaragaman ( $\left.H^{\prime}\right)$ sedang, indeks keseragaman (E) tinggi dan indeks dominasi $(C)$ rendah.
\end{abstract}

Kata Kunci: Struktur Komunitas, Makrozoobentos Epifauna, Lamun, Mangrove, Terumbu Karang. 


\section{PENDAHULUAN}

Daerah pantai merupakan salah satu ekosistem yang produktif dan dinamis. Ekosistem tersebut memberikan berbagai kegunaan yang sangat penting bagi keberlangsungan hidup masyarakat. Kawasan pantai mempunyai 3 ekosistem penting yaitu ekosistem mangrove, lamun dan terumbu karang. Ekosistem tersebut memiliki hubungan atau keterkaitan satu sama lain. Mangrove berada diposisi depan sebelum lamun dan terumbu karang. Sedimen tidak akan mengarah ke lamun bila terdapat mangrove yang lebat sebaliknya bila mangrove tidak ada maka akan menutup lamun sehingga lamun akan terganggu dan mati. Hal ini juga berlaku bagi ekosistem berikutnya. Sehingga perubahan-perubahan yang terjadi pada ekosistem tersebut seperti rusaknya habitat hidupnya maka akan mengganggu kehidupan biota didalamnya salah satunya adalah makrozoobentos.

Pada tiga ekosistem tersebut tentunya memiliki perbedaan jenis biota makrozoobentos dan dominasinya. Makrozoobentos merupakan organisme dasar perairan yang hidupnya dipermukaan (epifauna) atau didalam (infauna) substrat dasar yang hidup sesil pada ekosistem pantai. Hal tersebut memberikan kita pemikiran bahwa makrozoobentos dapat dimanfaatkan sebagai parameter untuk menilai kualitas lingkungan disuatu perairan. Zulkifli dan Setiawan (2011) dalam Nangin (2015) menyatakan bahwa makrozoobentos adalah salah satu biota yang hidup diperairan (akuatik) dan menetap di dasar suatu perairan, yang bergerak relatif lambat serta berkemampuan untuk hidup cukup lama sehingga berkemampuan untuk mengetahui kondisi perairan. Menurut Brotowidjoyo (1995) dalam Sinyo dan Idris (2013) makrozoobentos merupakan salah satu biota yang penting karena memiliki sebaran distribusi yang luas di daerah pasut (intertidal).

Selain itu biota tersebut memiliki peran penting terhadap penguraian bahan organik serta bahan pencemar lingkungan lainnya seperti logam (Setiawan, 2010). Peran lain dari biota tersebut yaitu dalam siklus rantai makanan. Berdasarkan sumber-sumber penelitian tersebut maka perlu dilakukannya penelitian lanjut untuk mengetahui kondisi lingkungan perairan Pantai Barat Desa Labuhan Kecamatan Sepulu Bangkalan pada ekosistem mangrove, lamun dan terumbu karang menggunakan indeks struktur komunitas.

\section{MATERI DAN METODE}

Penelitian dilaksanakan pada bulan Februari 2019 dengan pengambilan sampel makrozoobentos pada masing-masing ekosistem. Penelitian tersebut bertempat di Konservasi Terumbu Karang Pantai Barat Desa Labuhan Kecamatan Sepuluh Kabupaten Bangkalan, Madura. Berikut ini merupakan peta lokasi penelitan (Gambar 1.)

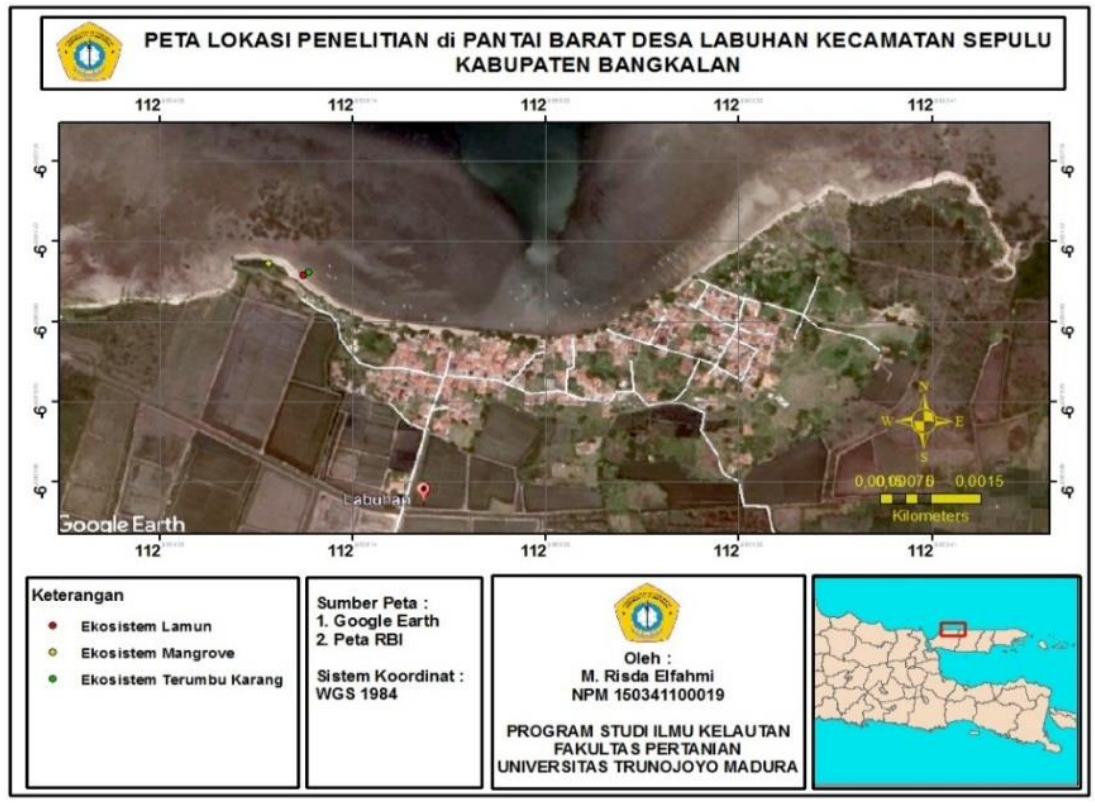

Gambar 1. Peta Lokasi Pengambilan Data Penelitian 
Sampel makrozoobentos yang diambil dari 3 ekosistem merupakan sampel penelitian utama yang akan dianalisis untuk menentukan perbedaan keberadaan jenis makrozoobentos di setiap ekosistem dan digunakan untuk mengetahui kesimpulan tingkat kualitas perairan di Pantai Barat Desa Labuhan Kecamatan Sepulu Kabupaten Bangkalan, Madura. Analisa biota makrozoobentos di laksanakan pada tanggal 20-21 Februari 2019 dan analisis sampel sedimen dilaksanakan pada tanggal 5-6 Maret 2019.

\section{Jenis dan Struktur Komunitas \\ Makrozoobenthos}

\section{Perhitungan Indeks Keanekaragaman}

Keanekaragaman suatu biota dapat ditentukan menggunakan teori informasi Shannon-Wienner $\left(H^{\prime}\right)$. Teori tersebut dapat dilakukan dalam penentuan tingkat kualitas perairan yang diteliti. Tujuan teori ini yaitu untuk menentukan tingkat keanekaragaman biota seperti makrozoobentos pada perairan tertentu. Rumus indeks keanekaragaman adalah sebagai berikut (Fachrul, 2007):

$H^{\prime}=-\sum_{i=1}^{s} P i \ln P i$

Keterangan:

$\mathrm{Pi}=$ jumlah individu tiap jenis $(\mathrm{i}=1,2,3, \ldots)$

$\mathrm{S}=$ jumlah jenis

$\mathrm{H}^{\prime}=$ indeks keanekaragaman jenis

Nilai keanekaragaman yang didapat selajutnya dapat dibandingkan dengan ting inkatan nilai indeks keanekaragaman makrozoobentos menurut Wilhm 1987 dalam Faris 2018. Tabel 1. berikut ini merupakan nilai tolak ukur indeks keanekaragaman makrozoobentos.

Tabel 1. Nilai Tolak Ukur Indeks Keanekaragaman

\begin{tabular}{ll}
\hline Nilai total tolak ukur & Keterangan \\
\hline$H^{\prime}<1,0$ & Tingkat keaneragaman rendah, maka penyebaran setiap spesies \\
& rendah dan kestabilan komunitasnya rendah. \\
$1,0<H^{\prime}<3,0$ & Tingkat keanekaragaman sedang, maka penyebaran tiap spesies \\
& sedang dan kestabilan komunitas sedang. \\
$H^{\prime}>3,0$ & Tingkat keanekaragaman tinggi, maka penyebaran tiap spesies \\
& tinggi dan kestabilan komunitas tinggi.
\end{tabular}

(Sumber: Wilhm 1987 dalam Faris 2018).

\section{Perhitungan Indeks Keseragaman}

$\mathrm{E}=\frac{H^{\prime}}{H^{\prime} \max }=\frac{H^{\prime}}{\ln (s)}$

Keterangan:

$\mathrm{S} \quad=$ jumlah spesies

$\mathrm{H}^{\prime} \mathrm{Max}=$ keragaman maksimum biota

$\mathrm{H}^{\prime} \quad=$ indeks keanekaragaman biota
$\mathrm{E} \quad=$ indeks keseragaman biota

Keragaman maksimum biota akan terjadi apabila telah ditemukan dalam kondisi semua spesies melimpah. Nilai E berkisar antara 0 dan 1, dimana apabila nilai keseragaman semakin mendekati nilai 1 menggambarkan bahwa semua spesies cukup melimpah.

Tabel 2. Nilai Tolak Ukur Indeks Keseragaman

\begin{tabular}{ll}
\hline Nilai total tolak ukur & Keterangan \\
\hline $\mathrm{E}<0,4$ & Nilai keseragaman mendekati 0 maka tingkat keseragamannya akan \\
& semakin rendah. Keseragaman kurang dari 0,4 dikategorikan rendah. \\
& Nilai keseragaman kurang dari atau sama dengan 0,6 dan nilai \\
& keseragaman makrozoobentos yang ditemukan memiliki hasil \\
perhitungan lebih besar atau sama dengan 0,4 maka dapat \\
dikategorikan sedang.
\end{tabular}

(Sumber: Brower et al., 1998 dalam Faris, 2018).

\section{Perhitungan Indeks Dominasi}

$C(D)=\sum_{i=1}^{s}\left(\frac{n_{i}}{N}\right)^{2}$
Keterangan:

$n_{i}=$ jumlah individu tiap jenis

$\mathrm{N}=$ jumlah keseluruhan individu 
Tabel 3. Nilai Tolak Ukur Indeks Dominasi

\begin{tabular}{ll}
\hline Nilai total tolak ukur & Keterangan \\
\hline Nilai C mendekati 0 & Jika dalam perhitungan nilai indeks dominasi (C) semakin \\
& mendekati angka 0 maka tidak terdapat dominasi \\
& makrozoobentos. Pada lokasi penelitian tersebut tidak ada \\
& dominasi dari salah satu jenis makrozoobentos. \\
Nilai C mendekati 1 & Jika dalam perhitungan nilai indeks dominasi (C) semakin \\
& mendekati angka 1 maka terdapat dominasi makrozoobentos. \\
& Pada lokasi penelitian tersebut didominasi oleh salah satu jenis \\
& makrozoobentos.
\end{tabular}

(Sumber: Odum, 1971 dalam Faris, 2018).

Menurut Odum (1993) dalam Payung (2017) tingkatan kriteria indeks dominasi (C) dibagi menjadi 3 tingkatan yaitu $0,00-0,50$ tergolong rendah, $0,5<\mathrm{C}<0,75$ tergolong sedang, dan 0,75 $<\mathrm{C}<1,0$ tergolong tinggi.

\section{HASIL DAN PEMBAHASAN \\ Struktur Komunitas Komposisi Spesies Makrozoobentos}

Komposisi jenis makrozoobenthos menggambarkan kekayaan jenis

Tabel 4. Komposisi Spesies Makrozoobentos Ekosistem Mangrove

\begin{tabular}{|c|c|c|c|c|c|}
\hline \multirow[b]{2}{*}{ No } & \multirow[b]{2}{*}{ Nama Spesies } & \multirow[b]{2}{*}{ Jenis Class } & \multicolumn{3}{|c|}{$\sum$ spesies } \\
\hline & & & Titik I & Titik II & Titik III \\
\hline 1. & Polymesoda erosa & Bivalvia & 1 & 0 & 1 \\
\hline 2. & Cheritidae cingulate & Gastropoda & 7 & 3 & 0 \\
\hline 3. & Telescopium telescopium & Gastropoda & 2 & 1 & 1 \\
\hline 4. & Cerithium coralium & Gastropoda & 14 & 7 & 14 \\
\hline \multicolumn{2}{|c|}{ Jumlah } & & 24 & 11 & 16 \\
\hline
\end{tabular}

Tabel 4. diatas menunjukkan bahwa pada ekosistem mangrove terdapat 4 spesies makrozoobentos dari kelas gastropoda dan bivalvia. Telescopium telescopium dan Cerithium makrozoobenthos yang terdapat di lingkunganya. Komposisi dan kepadatan makrozoobenthos yang ditemukan di setiap titik lokasi penelitian baik pada stasiun I (mangrove), stasiun II (Lamun) dan stasiun III (terumbu karang) memiliki jumlah komposisi spesies yang berbeda hal ini karena kondisi lingkungan yang berbeda. Komposisi spesies makrozoobenthos pada stasiun I dapat dilihat pada Tabel 4., stasiun II dapat dilihat pada Tabel 5., dan stasiun III dapat dilihat pada Tabel 6 . coralium di temukan di 3 titik lokasi. Sedangkan makrozoobentos spesies yang lain tidak ditemukan di salah satu titik lokasi.

Tabel 5. Komposisi Spesies Makrozoobentos Ekosistem Lamun

\begin{tabular}{cccccc}
\hline \multirow{2}{*}{ No } & \multirow{2}{*}{ Nama Spesies } & \multirow{2}{*}{ Jenis Class } & \multicolumn{3}{c}{$\sum$ spesies } \\
\cline { 4 - 6 } & & Gastropoda & 1 & 1 & 0 \\
\hline 1. & Trocus niloticus & Gastropoda & 1 & 2 & 1 \\
2. & Cypraea tigris & Gastropoda & 2 & 8 & 2 \\
3. & Aclisina turgida & Crustacea & 1 & 2 & 1 \\
4. & Harpiosquilla raphidea & Holothuroidea & 1 & 2 & 4 \\
5. & Holothuria edulis & & 6 & 15 & 8 \\
\hline Jumlah & & &
\end{tabular}

Tabel 5. diatas menunjukkan bahwa pada ekosistem lamun terdapat 5 spesies makrozoobentos dari kelas gastropoda, crustacea dan holothuroidea. Cypraea tigris,
Aclisina turgida, Harpiosquilla raphidea dan Holothuria edulis di temukan di 3 titik lokasi. Sedangkan makrozoobentos spesies Trocus niloticus tidak ditemukan di titik ke III. 
Elfahmi dan Efendy, Struktur Komunitas Makrozoobenthos

Tabel 6. Komposisi Spesies Makrozoobentos Ekosistem Terumbu Karang

\begin{tabular}{cccccc}
\hline \multirow{2}{*}{ No } & \multirow{2}{*}{ Nama Spesies } & \multirow{2}{*}{ Jenis Class } & \multicolumn{3}{c}{$\sum$ spesies } \\
\cline { 4 - 5 } & & Gastropoda & 4 & 3 & 2 \\
\hline 1. & Cerithium zonatum & Gastropoda & 2 & 2 & 0 \\
2. & Nassarius glans & Gastropoda & 0 & 0 & 3 \\
3. & Trocus niloticus & Gastropoda & 1 & 1 & 0 \\
4. & Cypraea annulus & Gastropoda & 2 & 1 & 2 \\
5. & Cypraea tigris & Bivalvia & 0 & 0 & 1 \\
6. & Atrina vexillum & Bivalvia & 2 & 1 & 2 \\
7. & Anadara granosa & Malacostraca & 1 & 0 & 0 \\
8. & Lophozozymus pictor & Holothuroidea & 1 & 2 & 1 \\
9. & Holothuria edulis & & 13 & 10 & 11 \\
\hline Jumlah & & & & \\
\hline
\end{tabular}

Tabel 6. diatas menunjukkan bahwa pada ekosistem terumbu karang terdapat 9 spesies makrozoobentos dari kelas gastropoda, bivalvia, Malacostra dan Holothuroida. Cerithium zonatum, Cypraea tigri, Anadara granosa dan Holothuria edulis di temukan di 3 titik lokasi. Sedangkan makrozoobentos spesies yang lain tidak ditemukan di salah satu titik lokasi.

\section{Kepadatan Makrozoobentos}

Kepadatan di definisikan sebagai jumlah individu persatuan luas. Menurut Setiawan (2019) dalam
Faris (2018). Kelimpahan dan keanekaragaman dari makrozoobenthos biasanya merupakan indikator adanya gangguan ekologi yang terjadi pada perairan sungai tersebut. Komposisi dan kepadatan makrozoobenthos yang ditemukan di setiap titik lokasi penelitian baik pada stasiun I (mangrove), stasiun II (Lamun) dan stasiun III (terumbu karang) memiliki nilai yang berbedabeda, hal ini dikarenakan kondisi lingkungan yang berbeda pula. Jumlah kepadatan makrozoobenthos pada stasiun I dapat dilihat pada Gambar 2.
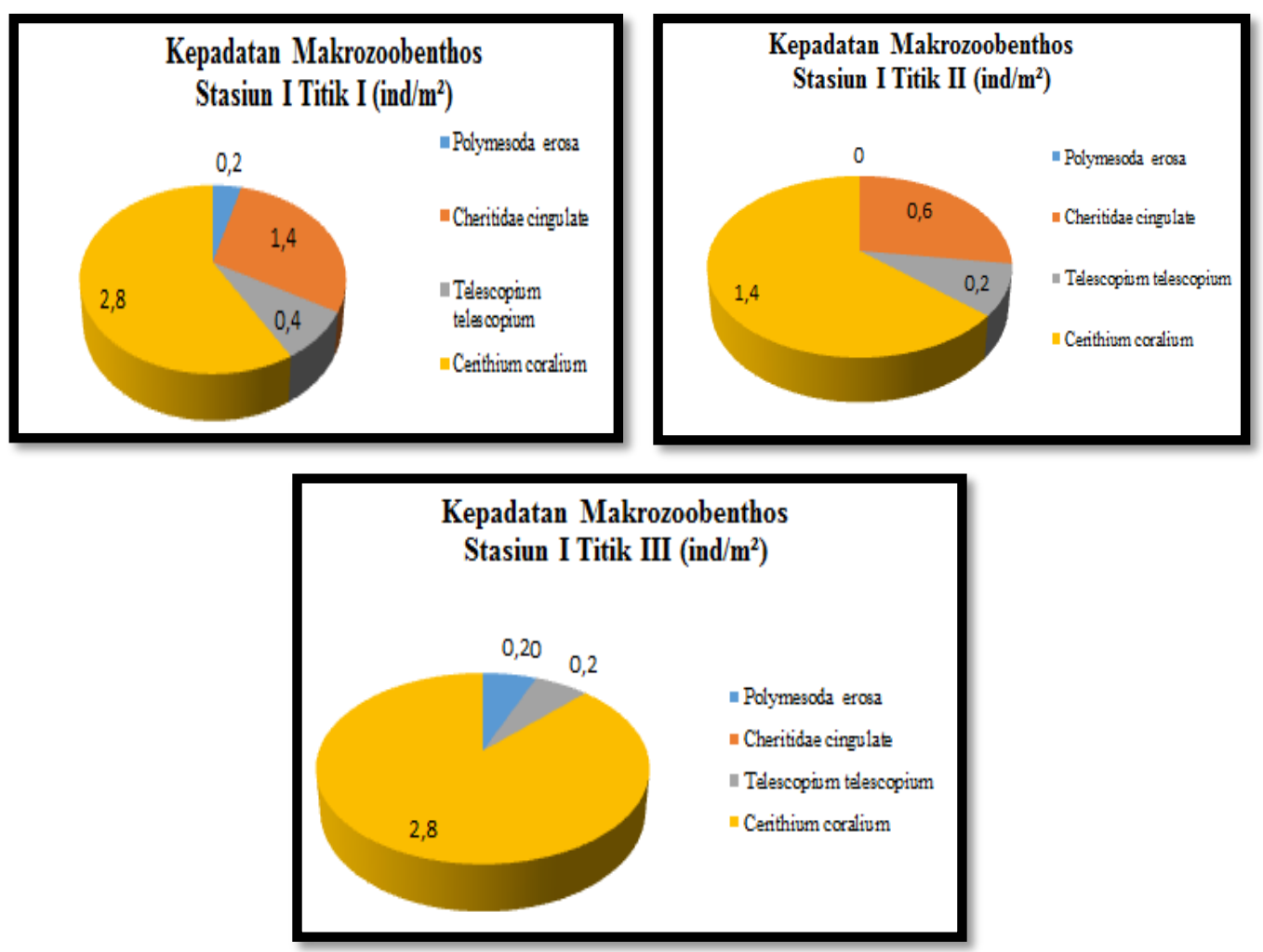

Gambar 2. Kepadatan Makrozoobenthos Stasiun I (Mangrove) 
Berdasarkan gambar diatas dapat diketahui pada pengambilan data makrozoobentos titik I pada ekosistem mangrove ditemukan 4 jenis makrozoobenthos, titik II ditemukan 3 jenis makrozoobentos dan titik III ditemukan 3 jenis makrozoobentos. Titik I, II dan III jenis Cerithium coralium berkisar antara 1,4-2,8 ind $/ \mathrm{m}^{2}$. Sedangkan jenis makrozoobenthos yang paling sedikit yang ditemukan adalah jenis Polymesoda erosa, Cheritidae cingulate dan Telescopium telescopium. Pada ke 3 titik lokasi ekosistem mangrove tersebut tergolong pada tingkat kerapatan mangrove sedang dan juga lokasi tersebut dekat dengan pemukiman dan tentunya mengalami interaksi langsung dengan aktifitas manusia seperti peletakan kapal dan disana lokasinya dekat dengan muara sungai. Selain itu faktor migrasi makrozoobenthos yang terdapat pada lokasi penelitan juga menjadi faktor yang cukup penting terhadap ditemukannya makrozoobenthos.

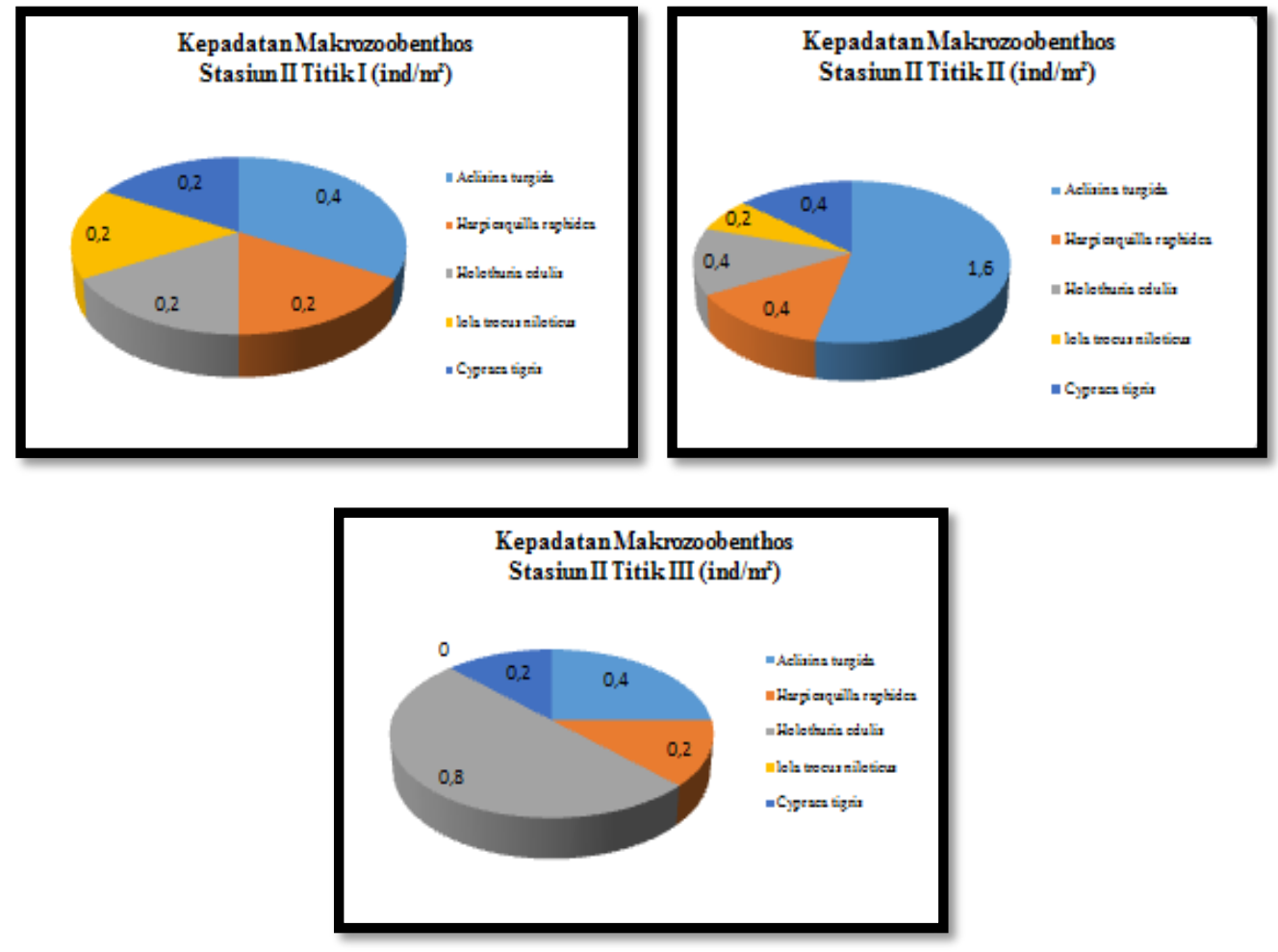

Gambar 3. Kepadatan Makrozoobenthos Stasiun II (Lamun)

Berdasarkan gambar diatas dapat diketahui pada pengambilan data makrozoobentos titik I pada ekosistem lamun ditemukan 5 jenis makrozoobenthos, titik II ditemukan 5 jenis makrozoobentos dan titik III ditemukan 4 jenis makrozoobentos. Titik I, II dan III jenis Aclisina berkisar antara 0,4-1,6 ind $/ \mathrm{m}^{2}$. Makrozoobenthos jenis ini banyak ditemukan di titik I dan titik II. Disamping itu makrozoobenthos jenis Holothuria edulis lebih banyak ditemukan di titik III. Sedangkan jenis makrozoobenthos yang paling sedikit yang ditemukan adalah jenis Harpiosquilla raphidea, trocus niloticus dan Cypraea tigris. Pada ke 3 titik lokasi ekosistem lamun tersebut tergolong pada tingkat kerapatan lamun sedang dan juga lokasi tersebut dekat dengan pemukiman dan tentunya mengalami interaksi langsung dengan aktifitas manusia. Selain itu faktor migrasi makrozoobenthos dan parameter lingkungan yang terdapat pada lokasi penelitan juga menjadi faktor yang cukup penting terhadap ditemukannya makrozoobenthos. Hal ini sesuai dengan penelitian Faris (2018) bahwa pada ekosistem lamun ditemukan makrozoobentos filum Molusca, Artropoda dan Echinodermata. 


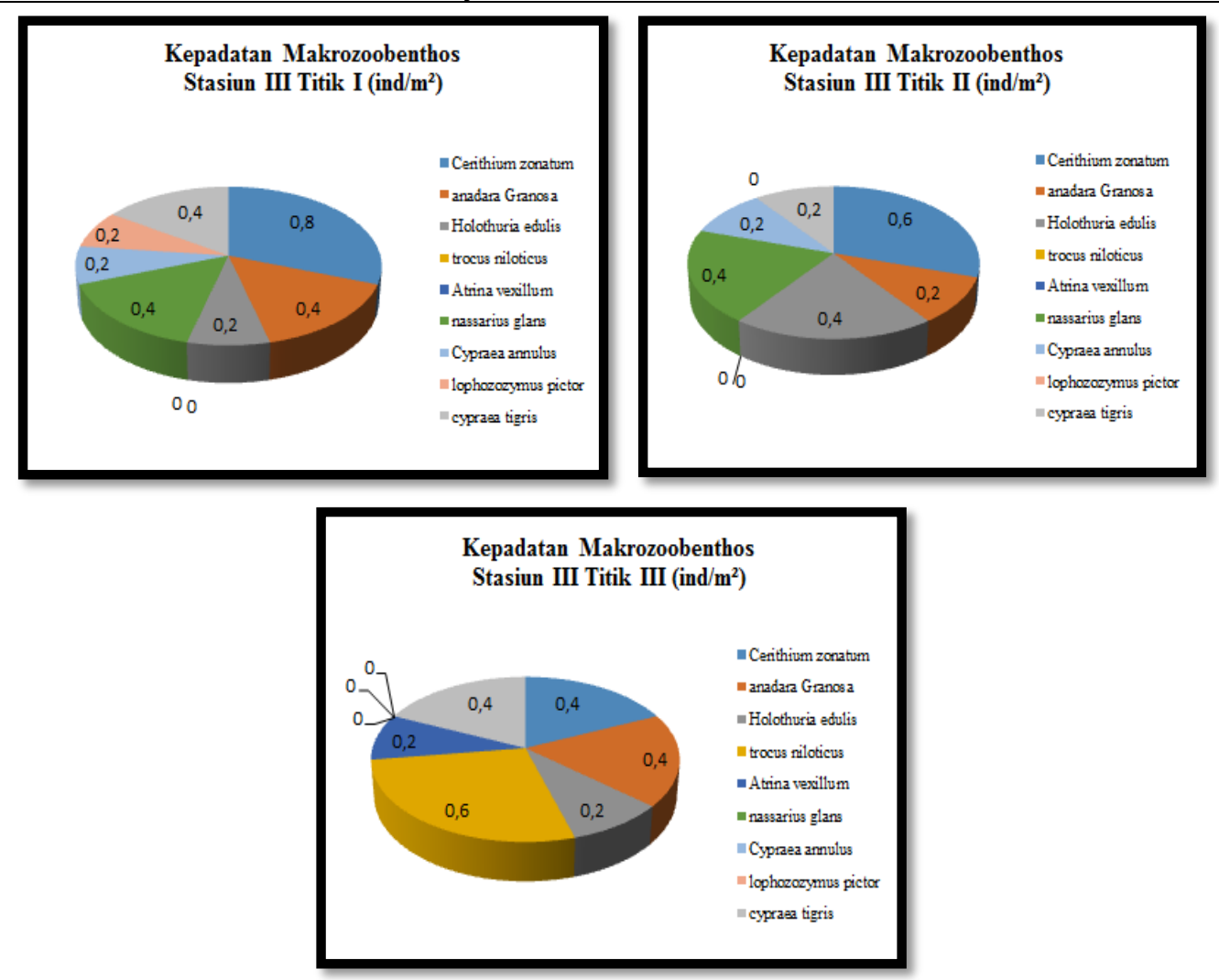

Gambar 4. Kepadatan Makrozoobenthos Stasiun III (Terumbu Karang)

Berdasarkan gambar diatas dapat diketahui pada pengambilan data makrozoobentos titik I pada ekosistem terumbu karang ditemukan 7 jenis makrozoobenthos, titik II ditemukan 6 jenis makrozoobentos dan titik III ditemukan 6 jenis makrozoobentos. Titik I, II dan III jenis Cerithium zonantum berkisar antara 0,4-0,8 ind $/ \mathrm{m}^{2}$. Sedangkan jenis makrozoobenthos yang paling sedikit yang ditemukan adalah jenis Anadara granosa, Holothuria edulis, trocus niloticus, atrina vexillum, nassarius glans, Cypraea annulus, Lophozozymus pictor, dan cyprea tigris. Pada ke 3 titik lokasi ekosistem terumbu karang dengan pemukiman dan tentunya mengalami interaksi langsung dengan aktifitas manusia seperti kerusakan terumbu karang karna jangkar kapal kecil. Selain itu faktor migrasi makrozoobenthos dan parameter lingkungan yang terdapat pada lokasi penelitan juga menjadi faktor yang cukup penting terhadap ditemukannya spesies makrozoobenthos.

\section{Struktur Komunitas Makrozoobenthos}

Hasil yang didapat dari penelitian yang dilaksanakan di sekitar Kawasan Konservasi Terumbu Karang Pantai Barat Desa Labuhan
Kecamatan Sepulu Kabupaten Bangkalan ditemukan 15 jenis makrozoobenthos dari ekosistem mangrove, ekosistem lamun dan ekosistem terumbu karang. Makrozoobenthos tersebut tergolong dari Filum Mollusca, Echinodermata dan Arthropoda. Pada 3 ekosistem tersebut filum mollusca lebih sering ditemukan.

Perbedaan kepadatan jenis makrozoobenthos yang didapat di setiap titik lokasi penelitian baik ekosistem mangrove, lamun, dan terumbu karang diduga terjadi karena beberapa faktor. Faktor yang mempengaruhi keberadaan makrozoobentos di perairan Desa Labuhan adalah suhu dimana sesuai dengan pernyataan menurut Hawkes (1978) dalam Payung (2017) bahwa suhu $35-40{ }^{\circ} \mathrm{C}$ merupakan titik kritis keidupan makrozoobentos maka tingginya suhu pada kawasan mangrove merupakan penyebab sedikitnya jenis makrozoobentos yang didapatkan. Untuk ekosistem lamun diketahui tingkat kerapatan lamun yang tergolong dalam kategori jarang yang menyebabkan jumlah makrozoobentos sedikit. Sedangkan penyebab yang menimbulkan beberapa jenis biota tidak ada 
Juvenil, 1(2), 260-268, (2020)

di titik lokasi tertentu adalah persen penutupan karang yang sedikit dan tempat perlintasan kapal nelayan yang membuat berpindahnya jenis makrozoobentos tertentu. Nilai perhitungan yang diperoleh meliputi indeks keanekaragaman $\left(\mathrm{H}^{\prime}\right)$ pada ekosistem lamun dan terumbu karang serta mangrove titik I tergolong dalam kriteria keanekaragaman sedang. Hal ini disesuaikan dengan tolak ukur keanekaragaman berdasarkan Wilhm (1987) dalam Masykur (2009) yang menentukan karakteristik dari lingkungan tersebut. Nilai tolak ukur sedang adalah dalam kriteria 1,0< $\mathrm{H}^{\prime}>3,0$ dimana menurut wilhm Tabel 7. Hasil Struktur Komunitas Makrozoobenthos
(1987) dalam (Faris 2018) "penyebaran tiap spesies sedang dan kestabilan komunitas sedang". Sedangkan pada ekosistem mangrove titik II dan III H'< 1,0 sehingga "penyebaran tiap spesies rendah dan kestabilan komunitas rendah". Hal ini diduga karena pengaruh aktivitas manusia serta akibat dari faktor parameter lingkungan seperti suhu dan lainnya yang tidak sesuai dengan tingkat standart baku mutu perairan untuk biota yang ditetapkan oleh Keputusan Menteri Lingkungan Hidup NO. 51 tahun 2004.

\begin{tabular}{|c|c|c|c|c|c|c|c|}
\hline No & Titik & $\mathrm{H}^{\prime}$ & Kriteria & $\mathbf{E}$ & Kriteria & C & Kriteria \\
\hline \multicolumn{8}{|c|}{ EKOSISTEM MANGROVE } \\
\hline 1. & Titik 1 & 1,013284 & Sedang & 0,73093 & Tinggi & 0,434028 & Rendah \\
\hline 2. & Titik 2 & 0,859967 & Rendah & 0,782776 & Tinggi & 0,487603 & Rendah \\
\hline 3. & Titik 3 & 0,463419 & Rendah & 0,421817 & Sedang & 0,773438 & Tinggi \\
\hline \multicolumn{8}{|c|}{ EKOSISTEM LAMUN } \\
\hline 4. & Titik 1 & 1,56071 & Sedang & 0,969724 & Tinggi & 0,222222 & Rendah \\
\hline 5. & Titik 2 & 1,321756 & Sedang & 0,821253 & Tinggi & 0,342222 & Rendah \\
\hline 6. & Titik 3 & 1,213008 & Sedang & 0,875 & Tinggi & 0,34375 & Rendah \\
\hline \multicolumn{8}{|c|}{ EKOSISTEM TERUMBU KARANG } \\
\hline 7. & Titik 1 & 1,818483 & Sedang & 0,934515 & Tinggi & 0,183432 & Rendah \\
\hline 8. & Titik 2 & 1,695743 & Sedang & 0,946412 & Tinggi & & Rendah \\
\hline 9. & Titik 3 & 1,502203 & Sedang & 0,838395 & Tinggi & 0,181818 & Rendah \\
\hline
\end{tabular}

Keseragaman makrozoobenthos dapat diketahui dari Indeks keseragamannya. Menurut Insafitri (2010) semakin kecil nilai indeks keanekaragaman $\left(\mathrm{H}^{\prime}\right)$ maka indeks Keseragaman $(E)$ juga akan semakin kecil yang dapat diartikan adanya dominasi suatu spesies terhadap spesies lain. Nilai indeks keseragaman dari ekosistem lamun dan terumbu karang serta mangrove titik I dan II tergolong pada kriteria tinggi yang sesuai dari kriteria nilai menurut Bengen (2000) yaitu E> 0,6. Sedangkan pada ekosistem mangrove titik III masuk kategori sedang yaitu $0,4 \leq E \leq 0,6$.

Hasil indeks Dominasi (Simpson) diketahui mendominasi hanya pada titik III pada ekosistem Mangrove dimana Menurut Odum (1971) dalam Faris (2018) apabila nilai dominasi mendekati 0 maka dikatakan tidak ada dominasi makrozzobentos dan apabila nilai dominasi mendekati 1 maka terdapat dominasi makrozoobenthos. Sehingga pada lokasi penelitian tersebut didominasi oleh salah satu jenis makrozoobenthos. Pada hasil perhitungan dominasi didapatkan kriteria dominan pada titik III ekosistem mangrove saja. Hal ini disebabkan jumlah makrozoobentos jenis cerithium coralium banyak ditemukan pada ekosistem mangrove titik III yaitu sebanyak 14 spesies.

Berdasarkan hasil perhitungan struktur komunitas makrozoobentos ekosistem mangrove mendapatkan nilai indeks keanekaragaman $\left(\mathrm{H}^{\prime}\right)$ yang rendah, indeks keseragaman $(\mathrm{E})$ sedang dan indeks dominasi (C) tinggi yang menandakan indikasi adanya tekanan yang berat dan ekosistem tidak stabil, penyebaran spesies rendah dan kestabilan komunitas rendah serta terjadinya dominasi suatu spesies yang tinggi. Ekosistem lamun dan terumbu karang memiliki nilai keanekaragaman $(\mathrm{H}$,$) sedang, indeks keseragaman (\mathrm{E})$ tinggi dan indeks dominasi $(\mathrm{C})$ rendah yang menandakan produktivitas lingkungan cukup, kondisi ekosistem cukup seimbang, tekanan ekologis sedang, penyebaran tiap spesies sedang dan kestabilan komunitas sedang sehingga tidak terjadinya dominasi dari suatu spesies.

Nilai struktur komunitas dari makrozoobenthos yang berbeda-beda di setiap titik lokasi disebabkan oleh jumlah jenis makrozoobenthos yang berbeda pula. Perbedaan itu dikarenakan 
kondisi lokasi yang berbeda di tiap lokasi dalam segi substrat dasar. Selain itu perbedaan nilai setiap indeks yang didapatkan dalam setiap lokasi diduga disebabkan oleh faktor migrasi makrozoobenthos dan faktor lingkungan sekitar perairan.

\section{KESIMPULAN DAN SARAN}

\section{Kesimpulan}

Hasil perhitungan struktur komunitas menunjukkan nilai indeks keanekaragaman $\left(\mathrm{H}^{\prime}\right)$ yang rendah, indeks keseragaman (E) sedang dan indeks dominasi $(\mathrm{C})$ tinggi yang menandakan indikasi adanya tekanan yang berat dan ekosistem tidak stabil, penyebaran spesies rendah dan kestabilan komunitas rendah serta terjadinya dominasi suatu spesies yang tinggi. Ekosistem lamun dan terumbu karang memiliki nilai keanekaragaman $(H$,$) sedang, indeks$ keseragaman (E) tinggi dan indeks dominasi $(C)$ rendah yang menandakan produktivitas lingkungan cukup, kondisi ekosistem cukup seimbang, tekanan ekologis sedang, penyebaran tiap spesies sedang dan kestabilan komunitas sedang sehingga tidak terjadinya dominasi dari suatu spesies.

\section{DAFTAR PUSTAKA}

Fachrul, M. F. 2007. Metode Sampling Bioekologi. Bumi Aksara. Jakarta.

Faris, A. S. 2018. Struktur Komunitas Makrozoobenthos di Kawasan Ekosistem Pesisir Pulau Sepanjang Kabupaten Sumenep. [Skripsi]. Fakultas Pertanian UTM. Bangkalan.

Nangin, S. R., Langoy, M. L., dan Katili, D. Y. 2015. Makrozoobentos sebagai Indikator Biologis dalam Menentukan Kualitas Air Sungai Suhuyon Sulawesi Utara. Jurnal MIPA UNSRAT. Vol 4 (2): 165-168.

Payung, W. R. 2017. Keanekaragaman Makrozoobentos (Epifauna) pada Ekosistem Mangrove di Sempadan Sungai Tallo Kota Makassar. [Skripsi]. Fakultas IImu Kelautan dan Perikanan. Universitas Hasanuddin. Makassar.

Sinyo, Y., dan Idris, J. 2013. Studi Kepadatan dan Keanekaragaman Jenis Organisme Bentos pada Daerah Padang Lamun di Perairan Pantai Kelurahan Kastela Kecamatan Pulau Ternate. Jurnal Bioedukasi. Vol 2 (1): 154-162. 